\title{
IMPACT OF TRANSFORMATIONAL LEADERSHIP ON TEACHER'S EMPLOYEE ENGAGEMENT OF STATE VOCATIONAL HIGH SCHOOLS
}

\section{lin Asikin*}

Student of Postgraduate Program in Educational Management Universitas Negeri Jakarta Indonesia

\section{Sylviana Murni}

Professor of Postgraduate Program in Educational Management Universitas Negeri Jakarta

Indonesia

\section{Ma'ruf Akbar}

Professor of Postgraduate Program in Educational Management Universitas Negeri Jakarta Indonesia

*Corrosponding author's Email:iin.gp13@gmail.com

Author's Biography

Iin Asikin is a student of postgraduate program in educational management in Universitas Negeri Jakarta, Jakarta, Indonesia.

Slyviana Murni is a professor and lecturer of postgraduate program in educational management in Universitas Negeri Jakarta, Jakarta, Indonesia with expertise in educational management, educational leadership, and educational assessment.

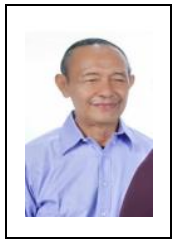

Ma'ruf Akbar is a professor and lecturer of postgraduate program in educational management in Universitas Negeri Jakarta, Jakarta, Indonesiawith expertise in educational management, educational leadership, and educational assessment. 


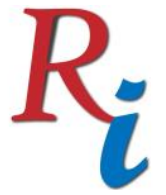

Asia Proceedings of Social Sciences

(APSS)

www.readersinsight.net/APSS

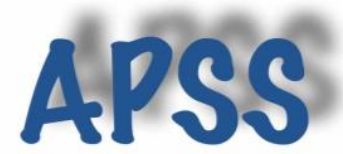

\section{Rese a r ch H i g h I igh t s}

This study aims to see whether there is a direct impact transformational leadership on the employee engagement of state vocational high school teachers in the Depok City, West province. This study uses a quantitative method with a survey approach. Data collection is done by questionnaire. The results showed that there was a direct impact transformational leadership on the employee engagement of state vocational high school teachers. This indicates that increasing teacher employee engagement can be done by increasing the role of transformational leadership.

\section{Research Objectives}

This study aims to see whether there is a direct impact transformational leadership on the employee engagement of state vocational high school teachers in the Depok City West province.

\section{Methodology}

This research is a quantitative study with a survey approach. In this research, the transformational leadership is an exogenous variable, and employee engagement is an endogen variable The study population was all 166 people of Depok City state vocational high school teachers and spread to 4 schools. The total sample of 118 people was obtained using the Slovin formula. Sampling is done by simple random sampling technique. The steps for sampling are: Establishing the school that will be used as the place of research (affordable population), looking at number of teachers in each school which is the unit of research analysis, establish a research sample (based on Slovin Formula known to 118 people), and determine the number of samples of each school to represent characteristics of the population. To obtain data in this research, a questionnaire was used for the two variables: transformational leadership (X1), and employee engagement (Y). All the questionnaires were filled in by teachers from The State Vocational High School in Depok. The analysis technique used is the path analysis.

\section{Results}

Based on the calculations from the path analysis, the direct impact transformational leadership on employee engagement, the coefficient value is 0,280 and $t_{\text {count }}=3,26$. The value of $t_{\text {table }}$ for $\alpha=0,05$ is 1,98 . Therefore, because the value of $t_{\text {count }}$ is more than the value of $t_{\text {table }}, \mathrm{H}_{0}$ is rejected and $\mathrm{H}_{1}$ is accepted. In other words, transformational leadership has a direct impact on employee engagement. The analysis of the hypothesis shows that transformational leadership has a direct and positive impact on employee engagement. Thus, it can be concluded that employee engagement impact directly and positively by transformational leadership. Increasing the role of transformational leadership will be able to increase teacher's employee engagement.

\section{Findings}

The hypothesis test concludes that transformational leadership has a direct impact on engagement. Previous research findings show that there is a significant positive influence of transformational leadership towards employee engagement (Kopperud, Martinsen, \& Humborstad, 2014); (Ghadi, Fernando, \& Caputi, 2013). Through transformational leadership style, principals can grow and increase the optimism and work engagement of employee 


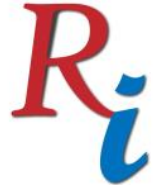

\section{Asia Proceedings of Social Sciences \\ (APSS) \\ www.readersinsight.net/APSS}

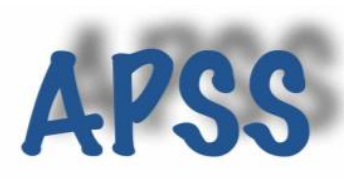

(Tims, Bakker, \& Xanthopoulou, 2011), one of them is by creating a conducive work environment. Transformational leadership can develop employees to become more engaged, especially if they can make them participate with organizational goals. In addition, the engagement of workers significantly affects loyalty and commitment when leaders succeed in adjusting transformational leadership (Mansor, Mun, Farhana, Nasuha, \& Tarmizi, 2017). The transformational leadership style makes the person have a positive outlook on himself and also uses the skills he has while working will strive to the fullest and feel engage and responsible for the success of the organization (Chaudari, Rangnekar, \& Barua, 2012). The influence of transformational leadership style on employee engagement can be explained that workers who are bound to try will display brilliant performance. (Laura C. Bartista, 2009).

\section{References}

Chaudari, R., Rangnekar, S., \& Barua, M. K. (2012). Impact of Occupational Self Efficacy on Employee Engagement an Indian Perspective. Journal of the Indian Academy of Applied Psychology

Ghadi, M. Y., Fernando, M., \& Caputi, P. (2013). Transformational Leadership and Work Engagement :The Mediating Effect of Meaning in Work. Leadership \& Organization Development, 34(6). doi: 10.1108/LODJ-10-2011-0110

Kopperud, K. H., Martinsen, O., \& Humborstad, S. I. W. (2014). Engaging Leaders in The Eyes of The Beholder : on The Relationship between Transformational Leadership, Work Engagagement, Service Climate, and Self-Other Agreement. Journal of Leadership and Organizational Studies, 21 (1), 29-42.

Laura C. Bartista, e. a. (2009). The Role of Leadership Style in Employee Engagement. Paper presented at the Proceedings of The Eight Annual Colleg of Education \&GSN Research Confernce, Miami Florida.

Mansor, Z. D., Mun, C. P., Farhana, B. S. N., Nasuha, W. A., \& Tarmizi, W. M. (2017). Influence of Transformation Leadership Style on Employee Engagement Among Generation Y,. Journal of economics and Management Engineering, Vol.11.

Tims, M., Bakker, A. B., \& Xanthopoulou, D. (2011). Do Transformational Leaders Enhance Their Followers"s Work Engagement? The Leadership Quarterly, 121-131. 